\title{
ETHICS OF PUBLIC ADMINISTRATION IN THE ADMINISTRATION OF GOVERNANCE IN INDONESIA
}

\author{
Zaidan Nawawi \\ Public Administration Science, Universitas Sjakhyakirti, Palembang, Indonesia \\ Email: zaidan_nawawi@yahoo.co.id
}

\begin{abstract}
Ethics is an important element which determines the successful implementation of organizations activities and public administration actors. The importance to implement public administration ethics in the Indonesia government bureaucracy was based to the ethical problems which happened, such as corruption, collusion and nepotism. This research used qualitative method, where is primary data obtained from observations, and secondary data obtained from media and literature study. From the research that has been conducted, it is known that few of government officials in Indonesia are lack of accountability in performing their duties, authorities and responsibilities and as a result the public bureaucracy in the reform era was much highlighted by the public and got criticism. To solve this problem, besides by enforcing the laws, the government also must to cultivate and implement the public administration ethics for their bureaucratic apparatus.
\end{abstract}

Key words: Ethics, Public Administration, Government, Indonesia, Bureaucratic.

\section{INTRODUCTION}

In recent months a lot of media coverage has again revealed various cases of corruption and abuse of power that occurred in the government bureaucracy, legislative and judicial institutions. The latest case of abuse of power is related to the alleged corruption that befell the former Chief Justice of the Constitutional Court $^{1}$ and the Governor of Banten. ${ }^{2}$ Not only the issue of corruption, violations of ethics in the form of abuse of power are also carried out by the Head of Region in other cases, such as the case of airport closure by civil service police officers allegedly carried out on the orders of unilateral Regent Ngada, East Nusa Tenggara.

\footnotetext{
${ }^{1}$ http://indeks.kompas.com/topik-

pilihan/list/2742/kasus.korupsi.akil.mochtar [Accessed on April 19, 2017]

${ }^{2}$ https://news.detik.com/berita/d-3441349/kasusalkes-ratu-atut-didakwa-rugikan-negara-rp-79miliar [Accessed on April 19, 2017]
}

Various cases are revealed and allegedly a form of abuse of power, indicating the neglect of ethical norms in the government bureaucracy. Ethical problems in public administration show a lack of attention or disregard for ethics in the practice of administering public administrations. Whereas ethics is an important element that determine the successful implementation of organizations activities and public administration actors. The reason is that moral values are contained in the whole process of public administration activities.

Today, ethics often becomes a concept that often "becomes number two" in governance. Ethics seems to be something that is not important and not interesting to be a discourse in the realm of government bureaucracy. As a result, the phenomenon of abuse of authority is rife, not only in the central government, it has even spread to the regions. 
Concepts of moral and ethical value in public administration are formulated to apply in the life of the state and the real scope of administration. The benefits of such an ethical conception will only be felt if it can truly be part of the modern administrative dynamic. In many ways, the philosophical concepts and theories about morality in the field of public administration are also derived from the practice of daily administration. Therefore, the discussion of the ethics of public administration is not in a vacuum, it must always include a discussion of its application, how bureaucrats and administrators act or must act according to existing ethical rules.

Related to various problems of abuse of governmental power, public administration ethics is one form of control over the government apparatus in implementing what is the main duty, function and authority. When the public administration wants its attitude, actions and behavior to be said to be good, then in carrying out its main tasks, its functions and authorities must rely on the ethics of public administration. Public administration ethics besides being used as a guide, reference, reference to public administration can also be used as a standard for determining attitudes, behaviors, and policies to be good or bad.

So many theories and concepts that discuss the normative norms that exist among the rulers of the state. Similarly, concepts such as justice, popular sovereignty, public interest, norms and so on. But sometimes the description contained in it is so abstract that it is difficult to understand.

\section{LITERATURE STUDY Ethics}

Ethics is a set of values as a guide, reference, guide what to do in carrying out its duties, but also serves as a standard to assess whether the nature, behavior, actions in the performance of the task is considered good or bad. Therefore, in ethics there is something of value that can give an assessment that something was said to be good or bad.

The term "ethics" is derived from the Greek ethos meaning "trait" or "custom" and the "ethical ta" invention phrase used by the philosophers of Plato and Aristotle (384-232 BCE) to explain their study of values and ideals Greece. So first, ethics is a matter of personal nature which includes what we call "being good," but it is also a matter of the whole nature of the whole society called its "ethos" (Solomon, 1987: 5).

Thinking about ethics takes place in three areas: (1) philosophical, (2) historical, and (3) categorical. At the philosophical level, ethics is discussed as an integral part of Philosophy, in addition to metaphysics, Epistemology, Aesthetics, and the like. In the historical area, ethics is studied as a particular ethical society in certain times, such as Greek and GraecoRoman Ethics, Mediaeval Ethics, whereas ethics at the categorical level is discussed as professional ethics, position ethics, and work ethics. As part of ethics, ethics of government lies in the categorial area, while as part of Governmental Science, on the philosophical level.

According to Bertens (2005: 6) based on the explanation in the Big Indonesian Dictionary (1988) put forward three meanings of the word ethics as follows. First, the word "ethics" is used in the sense: moral values and norms that 
hold a person or group in control of their behavior. Second, ethics as a set of principles or moral values, ie as a code of ethics. Third, the term "ethics" is used to designate the field of science, which is a reflective assessment of moral values in society by systematic and methodical research. In this sense, then ethics is a branch of philosophy that makes morality as its study or called moral philosophy.

\section{Ethics of Public Administration}

The use of public administration ethical terms is ambiguous. The term can mean as a science that discusses the ethical (moral) principles that underlie the actions of the government bureaucracy apparatus, especially in carrying out its duties and authority. In addition, there is another definition, namely the ethics of public administration as "a set of values that become the reference or guide for human action in the organization" as stated by Darwin (in Widodo, 2001: 252).

Widodo (2001) further refers to the opinions of Bertens and Darwin drawing the conclusion that ethics (including bureaucratic ethics) has two functions. First, as a guide or reference for state administration (public bureaucracy) in carrying out their duties and authority, so their actions in the organization was considered good, praiseworthy, and not blameworthy. Secondly, bureaucratic ethics as a standard of judgment, whether the nature, behavior and actions of the public bureaucracy (Public Administration) is considered good, not blameworthy and praiseworthy.

While according to Chandler and Plano (1982) the ethics of public administration is defined as follows: Ethics is the rules or standards governing, the moral conduct of the members of an organization or management profession", or in other words is the rules or standard of management which become a moral direction for public administrators in performing their duties to serve the public.

Within the scope of public

services, public administration ethics is defined as the philosophy and professional standard (code of ethics) or the right rules of conduct that should be obeyed by public service providers or public administrations

(Pasolong, 2007: 193). Thus it can be concluded that the ethics of public administration are rules or standards of management, moral direction for members of the organization or management work; Rules or standard of management which is the moral direction for public administrators in performing their duties to serve the community. The rules or

standards in the country's administrative ethics relate to personnel, supplies, finance, administration, and public relations.

\section{The Importance of Public Administration Ethics}

The importance of such public administration ethics is as follows (Henry, 1995: 400). The first is the reason for the public interest that must be fulfilled by the government, because the government has the responsibility in providing services. The government is expected to professionally carry out its duties and must take appropriate political decisions about who gets what, how much, where, when, and so on. In fact, the fact shows that the government does not have guidance or moral code of ethics adequately. The assumption that all government apparatus are those who have been tested and always defend the interests of the public or society, is not always true. Many cases 
prove that personal interests, families, groups, parties and even higher structures dictate the behavior of a bureaucrat or government apparatus. The bureaucrat in this case has no "independence" in ethical action, or in other words, there is no "ethical autonomy."

The second reason is more about the environment within the bureaucracy that provides the service itself. The third reason concerns the characteristics of the public public that are sometimes so varied that it requires special treatment. Hiring public servants using the principle of "conformity between the person and his job" is a principle that needs to be questioned ethically, because that principle will result in injustice, in which the employed candidate comes only from a relatively more advanced region.

The fourth reason is the opportunity to take action against the prevailing ethics of public service delivery. Public service is not as simple as imagined, or in other words, its complexity is both about the value of the service itself and of how to deliver the public service itself. This complexity and underpinning encourage public service providers to take professional measures based on "discretion". And this freedom often leads government officials to act not in accordance with the code of ethics or guidance of existing behavior.

\section{Governance}

Governance refers to "all of processes of governing, whether undertaken by a government, market or network, whether over a family, tribe, formal or informal organization or territory and whether through the laws, norms, power or language" (Bevir, 2013). Besides that, governance also relates to the processes of interaction and decisionmaking among the actors involved in a collective problem that lead to the creation, reinforcement, or reproduction of social norms and institutions (Hufty, 2011).

Stoker (1998: 17-18) describes governance refers to the development of governing styles in which boundaries between and within public and private sectors have become blurred. The essence of governance is its focus on mechanisms that do not rest on recourse to the authority and sanctions of government.... Governance for (some) is about the potential for contracting, franchising and new forms of regulation. In short, it is about what (some) refer to as the new public management. However, governance... is more than a new set of managerial tools. It is also about more than achieving greater efficiency in the production of public services.

Peters and Pierre (1998: 232) agree, saying that governance is about process. Governance is ultimately concerned with creating the conditions for ordered rule and collective action (Stoker, 1998; Peters and Pierre, 1998; Milward and Provan, 2000). As Stoker (1998: 17) notes, the outputs of governance are not different from those of government; it is instead a matter of a difference in processes. Governance refers to the development of governing styles in which boundaries between and within public and private sectors have become blurred. The essence of governance, and its most troublesome aspect, according to its critics, is a focus on mechanisms that do not rest on recourse to the authority and sanctions of government (Bekke, et.al, 1995; Peters and Pierre, 1998; Stoker, 1998; Rhodes, 1996, 1997). 


\section{METHODS}

Research uses qualitative methods. Sources of data in the study comes from primary and secondary data. Primary data obtained from observations on the implementation of public administration ethics in governance in Indonesia. Secondary data obtained from media and literature study. The data obtained for previous research is validated through cross check data with triangulation technique of data source.

\section{DISCUSSION}

The bureaucratic apparatus has more ethical obligations in relation to its behavior than the private. Similarly, high level bureaucratic apparatus in government bodies has more ethical obligations than others. A further implication of that opinion is that every bureaucratic apparatus is obliged to have a mental attitude and behavior that reflects the superiority of character, virtue, and various ethical principles derived from moral virtue, especially justice. Without these ethical principles a bureaucratic apparatus is unlikely to be able to nurture a nation's life and create a peaceful and prosperous society. Even the reverse, people's lives may be plunged into anxiety and misery.

Therefore, every bureaucratic apparatus is obliged to understand the ethical principles derived from various moral virtues, then nurture themselves so as to truly live up to the ethical principles, and lastly apply them as much as possible in their actions.

The various ethical principles in government administration are:

1. Responsibility

This ethical principle involves the desire of a bureaucratic apparatus to assume the obligation with full responsibility, and strong ties to perform all tasks and work satisfactorily. The bureaucratic apparatus must have a great desire to carry out its functions effectively, fully, and in the most satisfying way. Accountability is directed to the people, institutions and their direct

supervisors. The tendency to relinquish responsibility or willingness to throw responsibilities to others, or the habit of proposing "just following orders" should be eliminated from every good bureaucratic apparatus. Every bureaucratic apparatus must be prepared to assume accountability about what it does. They are should not be stuck on the excuse that he/she is merely following the instructions or implementing the government's policies.

2. Dedication

Devotion is a harsh desire to carry out the tasks of work with all the energy (mind and muscle or mental and physical), all passionate zeal, and full of selfless concerns of a personal nature such as wanting to be promoted or merged. Every bureaucratic apparatus in the execution of its duties must always and continuously show the involvement of self (involvement of self) and full of enthusiasm. The tendency to work halfheartedly or carelessly should not exist within any good bureaucratic apparatus. This devotion is directed to their position, expertise, and profession.

3. Loyalty

This ethical principle is the awareness of an officer to be sincerely obedient to the goals of the nation, the constitution of the state, the 
legislation, the agency, the duties of office and the superior for the achievement of mutual ideals. The execution of duplicate job duties, profit or loss considerations or even with the habit of sabotage should not be known in any good bureaucratic apparatus. If a bureaucratic apparatus is unable to carry out their duties in full capacity, not willing to be bound by his agency or not being compatible with the wisdom of his boss, then the ethical action is to resign from office.

4. Sensitivity

This ethical principle reflects the willingness and ability of a bureaucratic apparatus to pay attention to and alert to new developments, changing circumstances, and needs that arise in the life of the community from time to time with the best efforts to respond. Attitudes that do not care, as long as the routine task has been completed, or do not want to laboriously renewed, must also be removed from the self.

5. Equality

One of the principal virtues of government bodies aimed at serving all peoples and serving the common good is fair treatment. The fair treatment can usually be realized by giving equal treatment without discrimination or favoritism to all parties. So equality in treatment, service, and devotion must be given by every bureaucratic apparatus to the public regardless of relatives, political ties, genetic origin or social standing. The arbitrary or personal discrimination of treatment shall not be exercised by any fair bureaucratic apparatus.

\section{Equity}

The equality of treatment of all parties as an ethical principle does not always achieve justice and fairness. Issues and needs in the community are so diverse that it requires different treatment as long as it is based on fair judgment or the right reason. Thus, with respect to a particular group and for a given situation it is necessary to treat the same. But against another group and under different special conditions it may be necessary to have unequal treatment. For that reason to be considered is propriety. The principle of propriety refers to a matter which is appropriate according to the moral or ethical considerations that apply in people's lives.

(Gie, 1988: 71-74)

Based on the monitoring results of Indonesia Corruption Watch (ICW) against the verdict of corruption, it is known that corruption crime is observed mostly by Civil Servant (PNS) actors. Throughout the first six months of 2016, 134 civil servants have been convicted by court because of corruption cases. The number increases from year to year. In the year 2014 and then, the number of civil servants who are trapped in reaching 101 people. While in 2015, the number reached 104 people. Since 2012 until 2016, there are a total of 448 civil servants who are caught in corruption cases. ${ }^{3}$

The conditions mentioned above become a problem that needs to be resolved by the government, because if not then the government will lose the trust of the community. Efforts to prevent bureaucratic apparatus from doing

\footnotetext{
${ }^{3}$ http://www.antikorupsi.org/id/content/pegawainegeri-sipil-jadi-aktor-paling-banyak-terjeratkorupsi
} 
corruption should be done by not only enforcing the law, but also by instilling the importance of applying public ethics by the apparatus. With the cultivation of public ethics, the government apparatus awakens its awareness to provide the best public service for the community, including avoidance of deviant behavior, such as corruption, collusion and nepotism.

An ethical government apparatus then he will do his job responsibly, the values of accountability and professionalism will always be maintained by them. While public confidence in the government apparatus is declining due to the actions of government officials who do not reflect a sense of concern and sensitivity to the aspirations of the people, a good government apparatus will always try to improve his performance. In some cases, the study finds that there is a good commitment from some government apparatuses, both at the central and regional levels, to eliminate the culture of corruption, inculcate professionalism, transparency and accountability.

\section{Corruption as One Form of Public Administration Ethics Violation}

Corruption can be interpreted as an act of using public goods, can be in the form of money and services, for the benefit of enriching themselves, and not for the public interest. Judging from the process of occurrence, this corruption behavior can be divided into three forms, namely Graft, Bribery, and Nepotism.

Graft, is an internal corruption. This means that corruption is done without seeing a third party. Such as using or taking goods and money belonging to the organization, take advantage of position for self-interest. This corruption occurs because they have a position in the office. With his authority, the subordinates can not refuse the request of his boss. Rejecting or preventing his / her boss's request is considered an unlawful act against your boss. Even often, before the boss asks, subordinates have prepared everything needed by superiors.

While bribery, is an act of corruption that involves others outside himself (instansinya). Hence corruption is often referred to as corruption that is external. This means that corruption will not happen if no one else is doing bribery against him. The act of giving something (bribery, lubricant) is intended to influence the objectivity of making decisions, or the decisions made will benefit the giver or bribe.

Giving something (bribery) can be money, material, but it can also be a service. Corruption of this kind often occurs in offices / agencies that have service duties, issuing permits, recommendations, and so forth. The services provided by the government are often inhibited, not smooth, but this problem is not because the system and procedures are not good but because deliberately exacerbated by unscrupulous bureaucrats So that people who have the need, prefer to take care of licensing through brokers, or by giving bribes in the form of money to the government apparatus for the affairs to be smooth.

While nepotism, is an act of corruption in the form of decision-making tendencies that are not based on objective, rational considerations, but based on considerations of "nepitis", "kinship", such as friends, family, class, officials, and so forth. Decision-making considerations are often for the benefit of the person making the decision. They will be more secure if 
the people around them (subordinates) are people who are still "nepotis" or still have a relationship as a close relative. If they make a deviation, they will be safe and protected.

Actually corruption for the Indonesian people is considered as a deviant act perpetrated by one or several persons within a government organization. Due to corrupt behavior associated with ethical deviations of officials or public employees, generally the perpetrators of corruption will be punished, can be shunned, censured, cornered, and even terminated the fate of his career. This corrupt behavior is perceived by society as a distorted, bad, and reprehensible act.

Corruption is an act that deviates from ethical values. In "psychosociological", an action that deviates from the value due to the convergence of factors "intention or willingness" and "opportunity". If there is intention to commit acts of corruption, while the opportunity does not exist, then the action will not happen. Conversely, there is an opportunity to corrupt, but in itself there is no intention or willingness to do maladministration, then the action will also not happen.

With reference to the above view, it can be found two factors that cause corruption and mal-administration in Indonesia. First internal factors, that is personal factor of people who commit acts of corruption and mal-administration. Secondly, external factors, those factors come from outside a person, can be due to weak legislation, weak implementation of supervision, and a work environment that allows open opportunities for corruption and mal-administration.

\section{Bureaucratic Ethics: As Efforts to Prevent Corruption}

Corruption may occur at anytime and anywhere during a meeting of intentions and occasions, as has been pointed out earlier. Corruption, collusion and nepotism in Indonesia occur at the level of bureaucracy at high, middle and low levels. Therefore, to prevent or deal with corruption, the government should strive not to bring together intentions and opportunities for corruption. One of the efforts to prevent the unfairness of the two is to uphold bureaucratic ethics in the bureaucracy.

Bureaucratic ethical values as described above, if it really has become a "norm" to be followed and obeyed for the public bureaucracy in carrying out its duties and authorities, it will be able to prevent corruption in the body of public bureaucracy even though there is no supervisory agency as mentioned above. However, the bureaucratic ethics are not enough to ensure that corrupt behavior is not done in the bureaucracy. The most important thing is to return to the personality of each of the actors (human beings). In other words, internal control is in the form of faith and religion inherent in the human person.

\section{CONCLUSION}

Government is essentially a service to the community. It is not held to serve oneself, but to serve the community and to create conditions that enable every member of the community to develop the ability and creativity to achieve common goals. The paradigm of governance has shifted from the paradigm of "rule government" to "good governance". The government that always holds to the paradigm of "rule government" is always 
more relies on the prevailing laws and regulations. In contrast to "good governance", in the administration of government, development and public services are not solely based on government or state, but must involve all elements, both within the internal bureaucracy and outside the public bureaucracy.

State administration (public bureaucracy) as a state institution that fulfills the mission of fulfilling public interest, is held accountable to the public that it serves. There are three important things concerning the responsibility of state administration to the public that is accountability, responsibility, and responsiveness (Darwin, 1997: 72)

In reality, however, few of government officials are lack from accountability in performing their duties, authorities and responsibilities. As a result the public bureaucracy in the reform era was much highlighted by the public and got criticism. The focus is more on malicious practices (mal-administration) of public administration ethics in carrying out its duties and responsibilities. The forms of mal-administration may be corruption, collusion, nepotism, inefficiency, and unprofessionalism. The form of maladministration in general is more related to the behavior of individuals who occupy a position. To solve this problem, besides by enforcing the laws, the government also must to cultivate and implement the public administration ethics for the bureaucratic apparatus.

\section{REFERENCE}

Bekke, H., W. Kickert and J. Kooiman. 1995; "Public Management and Governance." In Kickert and F. A. van Vught, eds. Public Policy and
Administrative Sciences in the Netherlands. London: HarvesterWheatsheaf.

Bertens, K. (2005). Etika. Jakarta: Gramedia Pustaka Utama.

Bevir, Mark. (2013). Governance: A very short introduction. Oxford, UK: Oxford University Press.

Chandler, Ralph C., Plano, Jack C. (1982). Stock Image Public Administration Dictionary. New York: John Wiley \& Sons Inc.

Gie, The Liang. (1988). Etika Administrasi Pemerintahan. Cetakan ke-1. Jakarta: Karunika Universitas Terbuka.

Henry, S. (1995). Kinerja dalam Organisasi. Yogyakarta: Kanisius.

Hufty, Marc. (2011). "Investigating Policy Processes: The Governance Analytical Framework (GAF)." In: Wiesmann, U., Hurni, H., et al. eds. Research for Sustainable Development: $\quad$ Foundations, Experiences, and Perspectives. Bern: Geographica Bernensia, 403-424.

Milward, H. B., ed. (1996). Symposium on "The Hollow State: Capacity, Control and Performance in Interorganizational Settings." Journal of Public Administration Research and Theory. Vol. 6, No. 2: 193-313.

Pasolong, Harbani. (2007). Teori Administrasi Publik. Bandung: Alfabeta.

Peters, B. G. and J. Pierre. 1998. "Governance Without Government? Rethinking Public Administration." Journal of Public Administration Research and Theory, Vol. 8, No. 2: 223-243.

Rhodes, R. 1996. "The New Governance: Governing without Government." Political Studies, No. 44: 652-657.

Solomon, R,C. 1987. Etika Suatu Pengantar. Jakarta: Penerbit Erlangga.

Stoker, G. 1998. "Governance as Theory: Five Propositions." International 
Social Science Journal, Vol. 50, No. 1: 17-28.

Widodo, J. (2001). Good Governance: Telaah dari Dimensi: Akuntabilitas dan Kontrol Birokrasi pada Era Desentralisasi dan Otonomi Daerah. Surabaya: Insan Cedekia 